\title{
Botanical Briefs: Bloodroot (Sanguinaria canadensis)
}

\author{
Lauren Schwartzberg, DO; Sandra S. Osswald, MD; Dirk M. Elston, MD
}

\section{PRACTICE POINTS}

- Bloodroot (Sanguinaria canadensis) is a plant historically used in Mohs micrographic surgery as chemopaste.

- Bloodroot has been shown to have remarkable antimicrobial effects.

- The alkaloids of $S$ canadensis are nonspecific in their cytotoxicity, damaging both neoplastic and healthy tissue. They have been shown to cause skin erosions and cellular atypia.

Bloodroot (Sanguinaria canadensis) is a plant that historically has been used in medicine for its antimicrobial, antihypertensive, anti-inflammatory, and antineoplastic properties. In dermatology, bloodroot has been utilized for its cytotoxic effects; it has been marketed as black salve as an anticancer treatment, but it does not come without notable toxicities. Unwanted cosmetic outcomes and even irreversible scarring and premalignant conditions have been reported. This article aims to bring awareness to both the therapeutic potential of $S$ canadensis as well as the potential toxicities and risks associated with this North American plant.

Cutis. 2021;108:212-214.
(Figure). The plant thrives in wooded areas and grows to 12 inches tall. In its off-season, the plant remains dormant and can survive below-freezing temperatures. ${ }^{4}$

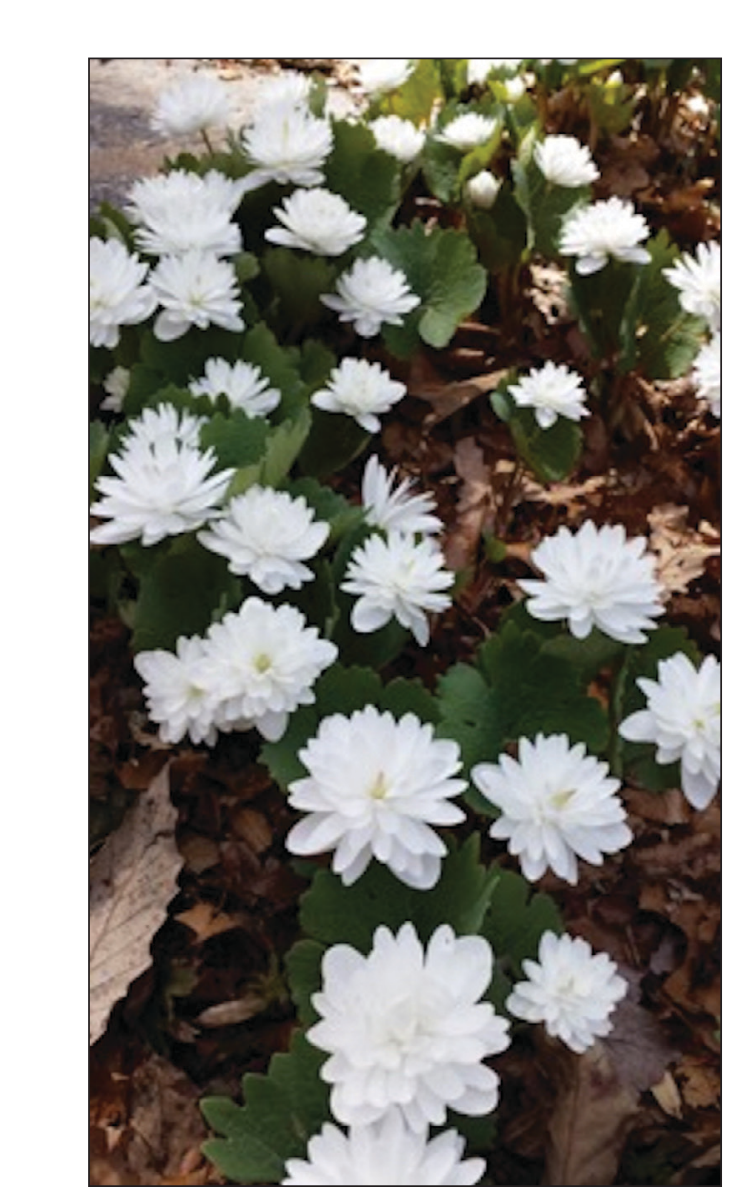

Flowered bloodroot (Sanguinaria canadensis). March, and fruits in June. The flowers comprise 8 to 10 white petals, surrounding a bed of yellow stamens

Dr. Schwartzberg is from the Department of Medicine, Lehigh Valley Health Network, Allentown, Pennsylvania. Dr. Osswald is from the Department of Dermatology and Cutaneous Surgery, UT Health San Antonio, Texas. Dr. Elston is from the Department of Dermatology and Dermatologic Surgery, Medical University of South Carolina, Charleston.

The authors report no conflict of interest.

Correspondence: Dirk M. Elston, MD, Department of Dermatology and Dermatologic Surgery, Medical University of South Carolina, 135 Rutledge Ave, MSC 578, Charleston, SC 29425 (elstond@musc.edu).

doi:10.12788/cutis.0345 


\section{Chemical Constituents}

Bloodroot gets its colloquial name from its red sap, which is released when the plant's rhizome is cut. This sap contains a high concentration of alkaloids that are used for protection against predators. The rhizome itself has a rusty, red-brown color; the roots are a brighter red-orange. ${ }^{4}$

The rhizome of $S$ canadensis contains the highest concentration of active alkaloids; the roots also contain these chemicals, though to a lesser degree; and the leaves, flowers, and fruits harvest approximately $1 \%$ of the alkaloids found in the roots. ${ }^{4}$ The concentration of alkaloids can vary from one plant to the next, depending on environmental conditions. ${ }^{5,6}$

The major alkaloids in $S$ canadensis include both quaternary benzophenanthridine alkaloids (eg, sanguinarine, chelerythrine, sanguilutine, chelilutine, sanguirubine, chelirubine) and protopin alkaloids (eg, protopine, allocryptopine)., ${ }^{3,7}$ Of these, sanguinarine and chelerythrine typically are the most potent. ${ }^{1}$ Oral ingestion or topical application of these molecules can have therapeutic and toxic effects. ${ }^{8}$

\section{Biophysiological Effects}

Bloodroot has been shown to have remarkable antimicrobial effects. ${ }^{9}$ The plant produces hydrogen peroxide and superoxide anion. ${ }^{10}$ These mediators cause oxidative stress, thus inducing destruction of cellular DNA and the cell membrane. ${ }^{11}$ Although these effects can be helpful when fighting infection, they are not necessarily selective against healthy cells. ${ }^{12}$

Alkaloids of bloodroot also have cardiovascular therapeutic effects. Sanguinarine blocks angiotensin $\mathrm{H}$ and causes vasodilation, thus helping treat hypertension. ${ }^{13}$ It also acts as an inotrope by blocking the $\mathrm{Na}^{+} / \mathrm{K}^{+}$ATPase pump. These effects in a patient who is already taking digoxin can cause notable cardiotoxicity because the 2 drugs share a mechanism of action. ${ }^{14}$

Chelerythrine blocks production of cyclooxygenase 2 and prostaglandin $\mathrm{E}_{2} \cdot{ }^{15}$ This pathway modification results in anti-inflammatory effects that can help treat arthritis, edema, and other inflammatory conditions. ${ }^{16}$ Moreover, sanguinarine has demonstrated efficacy in numerous anticancer pathways, ${ }^{17}$ including downregulation of intercellular adhesion molecules, vascular cell adhesion molecules, and vascular endothelial growth factor (VEGF). ${ }^{18-20}$ BlockingVEGF is one way to inhibit angiogenesis, ${ }^{21}$ which is upregulated in tumor formation, thus sanguinarine can have an antiproliferative anticancer effect. ${ }^{22}$ Sanguinarine also upregulates molecules such as nuclear factor- $\mathrm{kB}$ and the protease enzymes known as caspases to cause proapoptotic effects, furthering its antitumor potential. ${ }^{23,24}$

\section{Treatment of Dermatologic Conditions}

The initial technique of Mohs micrographic surgery employed a chemopaste that utilized an extract of $S$ canadensis to preserve tissue. ${ }^{25}$ Outside the dermatologist's office, bloodroot is used as a topical home remedy for a variety of cutaneous conditions, including cancer, skin tags, and warts. ${ }^{26}$ Bloodroot is advertised as black salve, an alternative anticancer treatment. ${ }^{27,28}$

As useful as this natural agent sounds, it has a pitfall: The alkaloids of $S$ canadensis are nonspecific in their cytotoxicity, damaging neoplastic and healthy tissue. ${ }^{29}$ This cytotoxic effect can cause escharification through diffuse tissue destruction and has been observed to result in formation of a keloid scar. ${ }^{30}$ The alkaloids in black salve also have been shown to cause skin erosions and cellular atypia. ${ }^{28,31}$ Therefore, the utility of this escharotic in medical treatment is limited. ${ }^{32}$ Fortuitously, oral antibiotics and wound care can help address this adverse effect. ${ }^{28}$

Bloodroot was once used as a mouth rinse and toothpaste to treat gingivitis, but this application was later associated with oral leukoplakia, a premalignant condition. ${ }^{33}$ Leukoplakia associated with $S$ canadensis extract often is unremitting. Immediate discontinuation of the offending agent produces little regression, suggesting that cellular damage is irreversible. ${ }^{34}$

\section{Final Thoughts}

Although bloodroot demonstrates efficacy as a phytotherapeutic, it does come with notable toxicity. Physicians should warn patients of the unwanted cosmetic effects of black salve, especially oral products that incorporate sanguinarine. Adverse effects on the oropharynx can be irreversible, though the eschar associated with black salve can be treated with a topical or oral corticosteroid. ${ }^{29}$

\section{REFERENCES}

1. Vogel M, Lawson M, Sippl W, et al. Structure and mechanism of sanguinarine reductase, an enzyme of alkaloid detoxification. J Biol Chem. 2010;285:18397-18406. doi:10.1074/jbc.M109.088989

2. Maranda EL, Wang MX, Cortizo J, et al. Flower power-the versatility of bloodroot. JAMA Dermatol. 2016;152:824. doi:10.1001 /jamadermatol.2015.5522

3. Setzer WN. The phytochemistry of Cherokee aromatic medicinal plants. Medicines (Basel). 2018;5:121. doi:10.3390/medicines5040121

4. Croaker A, King GJ, Pyne JH, et al. Sanguinaria canadensis: traditional medicine, phytochemical composition, biological activities and current uses. Int J Mol Sci. 2016;17:1414. doi:10.3390/ijms17091414

5. Graf TN, Levine KE, Andrews ME, et al. Variability in the yield of benzophenanthridine alkaloids in wildcrafted vs cultivated bloodroot (Sanguinaria canadensis L.) J Agric Food Chem. 2007; 55:1205-1211. doi:10.1021/jf062498f

6. Bennett BC, Bell CR, Boulware RT. Geographic variation in alkaloid content of Sanguinaria canadensis (Papaveraceae). Rhodora. 1990;92:57-69.

7. Leaver CA, Yuan H, Wallen GR. Apoptotic activities of Sanguinaria canadensis: primary human keratinocytes, C-33A, and human papillomavirus HeLa cervical cancer lines. Integr Med (Encinitas). 2018;17:32-37.

8. Kutchan TM. Molecular genetics of plant alkaloid biosynthesis. In: Cordell GA, ed. The Alkaloids. Vol 50. Elsevier Science Publishing Co, Inc; 1997:257-316.

9. Obiang-Obounou BW, Kang O-H, Choi J-G, et al. The mechanism of action of sanguinarine against methicillin-resistant Staphylococcus aureus. J Toxicol Sci. 2011;36:277-283. doi:10.2131/jts.36.277

10. Żabka A, Winnicki K, Polit JT, et al. Sanguinarine-induced oxidative stress and apoptosis-like programmed cell death (AL-PCD) in root meristem cells of Allium cepa. Plant Physiol Biochem. 2017;112:193-206. doi:10.1016/j.plaphy.2017.01.004 
11. Kumar GS, Hazra S. Sanguinarine, a promising anticancer therapeutic: photochemical and nucleic acid binding properties. RSC Advances. 2014;4:56518-56531.

12. Ping G, Wang Y, Shen $L$, et al. Highly efficient complexation of sanguinarine alkaloid by carboxylatopillar[6]arene: $\mathrm{pK}_{\mathrm{a}}$ shift, increased solubility and enhanced antibacterial activity. Chemical Commun (Camb). 2017;53:7381-7384. doi:10.1039/c7cc02799k

13. Caballero-George C, Vanderheyden PM, Solis PN, et al. Biological screening of selected medicinal Panamanian plants by radioligand-binding techniques. Phytomedicine. 2001;8:59-70. doi:10.1078/0944-7113-00011

14. Seifen E, Adams RJ, Riemer RK. Sanguinarine: a positive inotropic alkaloid which inhibits cardiac Na+, K+-ATPase. Eur J Pharmacol. 1979;60:373-377. doi:10.1016/0014-2999(79)90245-0

15. Debprasad $\mathrm{C}$, Hemanta $\mathrm{M}$, Paromita $\mathrm{B}$, et al. Inhibition of $\mathrm{NO}_{2}$ PGE $_{2}$, TNF- $\alpha$, and iNOS EXpression by Shorea robusta L.: an ethnomedicine used for anti-inflammatory and analgesic activity. Evid Based Complement Alternat Med. 2012; 2012:254849. doi:10.1155/2012/254849

16. Melov S, Ravenscroft J, Malik S, et al. Extension of life-span with superoxide dismutase/catalase mimetics. Science. 2000;289:1567-1569. doi:10.1126/science.289.5484.1567

17. Basu P, Kumar GS. Sanguinarine and its role in chronic diseases. In: Gupta SC, Prasad S, Aggarwal BB, eds. Advances in Experimental Medicine and Biology: Anti-inflammatory Nutraceuticals and Chronic Diseases. Vol 928. Springer International Publishing; 2016:155-172.

18. Alasvand M, Assadollahi V, Ambra R, et al. Antiangiogenic effect of alkaloids. Oxid Med Cell Longev. 2019;2019:9475908. doi:10.1155/2019/9475908

19. Basini G, Santini SE, Bussolati S, et al. The plant alkaloid sanguinarine is a potential inhibitor of follicular angiogenesis. J Reprod Dev. 2007;53:573-579. doi:10.1262/jrd.18126

20. Xu J-Y, Meng Q-H, Chong Y, et al. Sanguinarine is a novelVEGF inhibitor involved in the suppression of angiogenesis and cell migration. Mol Clin Oncol. 2013;1:331-336. doi:10.3892/mco.2012.41

21. Lu K, Bhat M, Basu S. Plants and their active compounds: na ral molecules to target angiogenesis. Angiogenesis. 2016;19:287-295. doi:10.1007/s10456-016-9512-y

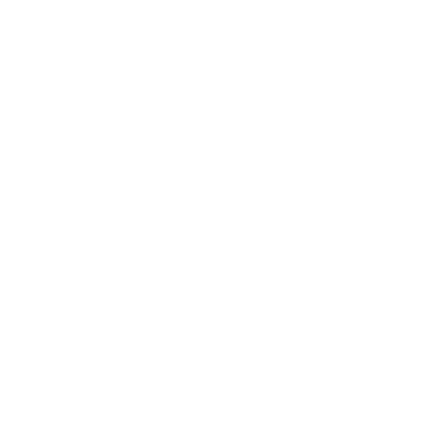

22. Achkar IW, Mraiche F, Mohammad RM, et al. Anticancer potential of sanguinarine for various human malignancies. Future Med Chem. 2017;9:933-950. doi:10.4155/fmc-2017-0041

23. Lee TK, Park C, Jeong S-J, et al. Sanguinarine induces apoptosis of human oral squamous cell carcinoma $\mathrm{KB}$ cells via inactivation of the PI3K/Akt signaling pathway. Drug Dev Res. 2016;77:227-240. doi:10.1002/ddr.21315

24. Gaziano R, Moroni G, Buè C, et al. Antitumor effects of the benzophenanthridine alkaloid sanguinarine: evidence and perspectives. World $J$ Gastrointest Oncol. 2016;8:30-39. doi:10.4251/wjgo.v8.i1.30

25. Mohs FE. Chemosurgery for skin cancer: fixed tissue and fresh tissue techniques. Arch Dermatol. 1976;112:211-215.

26. Affleck AG, Varma S. A case of do-it-yourself Mohs' surgery using bloodroot obtained from the internet. Br J Dermatol. 2007;157:10781079. doi:10.1111/j.1365-2133.2007.08180.x

27. Eastman KL, McFarland LV, Raugi GJ. Buyer beware: a black salve caution. J Am Acad Dermatol. 2011;65:E154-E155. doi:10.1016/j.jaad.2011.07.031

28. Osswald SS, Elston DM, Farley MF, et al. Self-treatment of a basal cell carcinoma with "black and yellow salve." J Am Acad Dermatol. 2005;53:508-510. doi:10.1016/j.jaad.2005.04.007

29. Schlichte MJ, Downing CP, Ramirez-Fort M, et al. Bloodroot associated eschar. Dermatol Online J. 2015,20:13030/qt05r0r2wr.

30. Wang MZ, Warshaw EM. Bloodroot. Dermatitis. 2012;23:281-283. doi:10.1097/DER.0b013e318273a4dd

31. Tan JM, Peters P, Ong N, et al. Histopathological features after topical black salye application. Australas J Dermatol. 2015;56:75-76.

32. Hou JL, Brewer JD. Black salve and bloodroot extract in dermatologic conditions. Cutis. 2015;95:309-311.

33. Eversole LR, Eversole GM, Kopcik J. Sanguinaria-associated oral leukoplakia: comparison with other benign and dysplastic leukoplakic lesions. Oral Surg Oral Med Oral Pathol Oral Radiol Endod. 2000;89:455464. doi:10.1016/s1079-2104(00)70125-9

34. Mascarenhas AK, Allen CM, Moeschberger ML. The association between Viadent ${ }^{\circledR}$ use and oral leukoplakia-results of a matched case-control study. J Public Health Dent. 2002;62:158-162. doi:10.1111/j.1752-7325.2002.tb03437.x 